\title{
Perception of the Selected Business Environment Aspects by Service Firms
}

\author{
Khurram Ajaz Khan \\ Faculty of Management and Economics, Tomas Bata University in Zlin, Czech \\ Republic \\ Gentjan Çera \\ Faculty of Management and Economics, Tomas Bata University in Zlin, Czech \\ Republic Vaclav Netek \\ Institute of Entrepreneurship and Marketing, University of Entrepreneurship and Law, \\ Czech Republic
}

Received: 10 October 2019. Revision received: 4 November 2019. Accepted: 22 November 2019

\begin{abstract}
The business environment is a profound concern for the state and institutions to make it encouraging to boost entrepreneurship. Given such relevance of the business environment, this paper aims to link selected business environment aspects to business sector. The study identified the perceived differences between sectors in the Czech and Slovak Republics and then a comparison of a similar group of firms. To shape the study, survey-based research planned and conducted in two segments of firm's (service and nonservice), covered 641 enterprises. The current research adopted factor analysis and then t-test and Mann-Whitney test to determine the results. The major findings of the study reveal that the Slovak firms in the service sector scored higher in macroeconomic environment, consumers' consumption and competition factors and lower in access to finance factor, as compared to their non-service counterparts. However, another key finding indicates that the Czech entrepreneurs' perception did not statistically differ in any selected aspects of business environment between the firms operating in service and non-service sectors. In all the cases business support was found insignificant. This paper adds to the existing literature in entrepreneurship by offering a better understanding of the linkage between business sector and business environment aspects.
\end{abstract}

Key words: business environment, SMEs, entrepreneurs, business sectors, Czech and Slovak Republics

JEL Classification: L26, O11, O14

\section{Introduction}

The economic development of any nation depends on three sectors, service, agricultural and manufacturing, and each sector have enterprises of different size and worth, contributing towards overall GDP growth (KPMG, 2015). Among them, the most number of, the backbone of the economy, fulfilling the needs within the nation as well as of bigger industries are small and medium enterprises. Small and medium enterprises have a key role in the economic acceleration of any nation and it plays a crucial role in employment generation, promoting innovation, competitiveness and economic growth (Kozubíková, Homolka, \& Kristalas, 2017; Noorali \& Gilaninia, 2017; Lewandowska \& Stopa, 2019). And there is a direct link between the emergence of entrepreneurship and 
small and medium enterprise's growth and development (Gosevska, Popovski, \& Markoski, 2013; Dvorský et al., 2019) and for the SMEs development and growth, the most vital ingredient is favorable business environment (Buno, Nadanyiova, \& Hraskova, 2015).

Business activities are comprehensively reliant on the business environment which include the conditions under which firms operate, or develop their action plan, have a weighty impact on their progress, competitiveness and growth possibilities (Trofimovs, 2017) it means the most essential condition for the growth, sustainability, and development of small and medium firms is quality of business environment and its persistent improvisation is the best way to support and stimulate individuals for start-ups as well as to improve their competitiveness among the peers (Buno et al., 2015) and all together varied conditions regarding legislation, institutional infrastructure, and market operations affect business environment (Chládková, 2015; Zajkowski \& Domańska, 2019). Therefore, the current study will inspect the selected variables affecting the business environment and will measure the perception of the selected variables by service and non-service firms in the Czech Republic and Slovakia. For the study, the firms are divided into two categories, firms produce and distribute services like retail, tourism, etc., and firms operate in other sectors such as manufacturing and agriculture.

According to Jean-Claude Juncker, European Commission president stated in the year 2015, investment and growth will improve if there will be better regulatory environment and promotion of entrepreneurship, regulations for the SMEs must be eased as they are major source of employment in Europe, therefore, regulatory restrictions for SMEs must be reduced (Dababneh et al., 2015). World Bank also stressed in the recently published report in 2019 considerable variances found in the business environment both between and within the European Union states. It was also found that location matters as some located at places have congenial business environment have better performance in term of sales, employment and productivity growth as well as in investments. Reduction in the cost of doing business for local firms increases their efficiency and competitiveness abroad and motivates investments which is important for the regional progress (WB, 2019). It indicates the European economy is principally depending on SMEs as it directly affects business growth, economic stability, and employment generation, and quality of business environment do affects their performance and progression, therefore, this study has identified that it is logical to examine the perception of the entrepreneurs, the key people for SMEs development and growth how is the current quality of the business environment, identify the major hurdle in business environment and suggest regarding the weak business environment for their improvement to nurture SMEs and also why it is crucial to provide better business environment for the stability and growth of the economic activities in the region on the basis of the firms feedback in service and nonservice firms in Czech republic as well as in Slovakia. Previous studies found significant differences in perception between the SMEs in the mentioned countries regarding the quality of business environment like state bureaucracy (Belas, Belas, Cepel, \& Rozsa, 2019; Androniceanu, 2017) considering the similar possibilities for the current study with other key business environment variables.

The economic situation in Europe is getting better year on year after the last decade's global economic meltdown. The past economic crisis had an extended effect on the growth and performance of SMEs in the whole region and affected adversely almost all the sectors and undoubtedly SMEs too. Stable economies were somehow managed to maintain their employability and productivity which helped them keep on progress including countries like Germany, the Czech Republic and Slovakia (Carla Drysdale, 2018). It has been identified that there are many factors affect firms within business 
environment, for the study five comparable factors has been identified which have been taken from previous published work in the similar areas of SMEs and firms, and the comparative analysis of their business environment evaluation in Czech Republic and Slovakia (Cepel, Belas, Rozsa, \& Strnad, 2019; Cepel, Stasiukynas, Kotaskova, \& Dvorsky, 2018; Kotaskova \& Rozsa, 2019, Ključnikov, Kozubíková, \& Sopková, 2017; Belas \& Sopkova, 2016; Vydrová and Bejtkovský, 2018).

As SMEs and entrepreneurs are the key driving force of the economy (RibeiroSoriano, 2017) and for the need of favorable business environment, it is significant and reasonable to keep on measuring firms environmental challenges and major hurdles to create a congenial environment for their flawless growth and development (Yoshino, 2016). Hence, to create a favorable environment it is noteworthy to know first the challenges and unfavorable environment perceived by the firms before drawing what is affecting them most as a study reveal that the perception about the quality of business environment is a multifaceted consisting of both economic and non-economic aspects (Cepel et al., 2019). The current study will investigate the five key factors selected from the previous published works macroeconomic, consumer, competition, access to finance and business support, and their impact on the quality of the business environment in two sections, first on service firm and non-service firms, and second between the service and non-services firms in the Czech Republic and Slovakia. The aim of the study to identify the statistical differences between the service and non-service firms and firms in the Czech Republic and Slovakia about the quality of the business environment. The outcome of the study will help to identify the perceive differences about the quality business environment between service and non-service firms as well as between the firms in the Czech Republic and Slovakia. Based on the outcome, the study will recommend selected variables of the business environment for the betterment to improve the quality of the business environment in both nations.

The paper is designed in the following sequence: The theoretical part establishes the relationship of factors that affects a firm's business environment and the logic behind the study is justified through a literature review of published articles and definitions. The second section will explain the aim, data collection and methods applied. The results will be analyzed on the basis of hypothesis test. At the final stage, finding \& discussion, conclusion and scope for further research will be stated.

\section{Literature review}

The current literature review will try to join the dots to build the relation on the following four points, first, factors affecting quality of business environment, second, focus will be on service and non-service firms, third, determine the perception of the quality of the business environments from service and non-service firms and identify the differences and fourth, the comparison of the key factors of quality of business environment, perceived differences by service \& non-service firms in the Czech Republic and Slovakia. This literature review is divided into two sections. The first section evaluates the factors of the quality of the business environment that are believed to have an impact on the firm's performance. In doing so, factors affecting the firm's business environment quality, identified factors are the Macro environment, Consumers, Access to finance, Business Support, Competition. The second part of this review of the literature will establish the relationship between factors of the business environment and firms through past research findings.

Firms keep doing environmental scanning to understand the changing environmental factors and their impact to understand and to frame and implement strategies as per the macro-environment within which it operates. Therefore, 
understanding the macro context of a business is crucial and its continuous scanning is a regular task for the business firms. Present study will focus on two groups of firms, service firms and non-service firms, dissimilar from product producers, service mechanisms are often not physical units, but rather are a grouping of processes, human skills, and resources that must be suitably unified to result in the desired service (Goldstein, Johnston, Duffy, \& Rao, 2002), the study will compare firms in two segments because services sector is showing stronger progress and employment performance (OECD, 2005) and there is pinpoint, is the quality of business environments affects service and non-service firms differently, hence, the undertaken study will find the quality of the business environment affecting service and non-service firms differently, this reflect rationality behind this study to compare the quality of business environment between the two major segment.

Business environment consists of rules and standards, laws and supervisory outlines, governance, and the overall policy about trade and investment, together with establish rules and regulation for business operations that may affect the business, market, flow of investment, cost of doing business and productivity positively or negatively (Dobes, Kot, Kramolis, \& Sopkova, 2017; Essia, 2012). Another study states the business environment includes wide-ranging external conditions within which businesses conduct their business activities (Chládková, 2015). The business environment is a set of economic, legal and institutional conditions that affect firms' behavior and it cannot be controlled by the firms (Bruothová \& Hurný, 2016). Business environment quality is an essential prerequisite for the successful development of SMEs (Kljucnikov, Belas, Kozubikova, \& Pasekova, 2016). A deprived tight and controlling environment can increase the cost of doing business with indirect effects to employment, output, investment, productivity, and living standards (Besley, 2015) and business environment must be steady with simple guidelines, simplified administrative requirements and nominal regulations (Chládková, 2015) and barriers of doing business also differ broadly through regions and nations (Commander \& Svejnar, 2011), therefore it is obvious to study the business environment affects across different firms and countries. That's why for the current study five major business environments are undertaken to study i.e., macro-environment, consumers, access to finance, business support, and competition.

Macroeconomic variables are also known as external factors (Angelini \& Foglia, 2018) and macroeconomic variables do influence systematic risks and these risks affect all companies to some degree (Çiftçi, 2014). Business performances cannot be parted from the impact of macroeconomic factors (Dewi, Soei, \& Surjoko, 2019) and macroeconomic factors do influence small and medium enterprises, at local and international levels (Bekeris, 2012) firms performance is often determined from steadiness in the macroeconomic factors (Egbunike \& Okerekeoti, 2018). Another study indicated macroeconomic environment impacts firm growth both directly and indirectly (Ipinnaiye, Dineen, \& Lenihan, 2017) it is undoubtedly clear that a stable and favorable macroeconomic environment is essential for firms positive performance and development as another study indicates a relationship between macro-environment factors and firms profitability (Bekeris, 2012; Hudáková \& Dvorský, 2018). Consumer plays a significant role in the business environment. Consumer preferences and buying trends are constantly changing (Yap \& Yazdanifard, 2014), and consumer demands drive businesses and their choices help firms to determine resource allocation. Firms need to comprehend in what way the consumers' tastes and consumption relatedly affect business profits (Kaufmann \& Panni, 2014). As businesses must respond to the demands of the consumer which can be traced through environmental analysis. Consumer consumption habits contribute to firms' sustainability. Firms can use marketing tools to understand consumers' needs and 
identify the factors influence the firm's production and business. Consumers can positively influence the quality of the business environment. Therefore, it is obvious to identify how the consumer environment is evaluated by the service and non-service firms.

Very few SME entrepreneurs are knowledgeable regarding the conditions under which banks grant loans (Kljucnikov, 2016; Kljucnikov \& Belas, 2016; Rahman, Belas, Kliestik, \& Tyll, 2017). Access to finance is being acknowledged as one of the most serious limitations for the firms' growth (Chávez, Koch-Saldarriaga, \& Maria, 2018). The majority of the firms do not have adequate access to financial resources for their activities and it is the most important factor for SMEs to sustain (Ahmedova, 2015). Firms who do not have restricted credit grow faster than firms that have restricted credit (Fowowe, 2017). Also, small and medium enterprises face more challenges for financing compare to big firms and bears higher costs and higher risk premiums (Chávez et al., 2018). Another study shows that interest rate, government regulations, and financial crises have a noteworthy connection to gain access to financial resources and it is vital to observe the key economic variables influencing access to finance (Saghir \& Aston, 2019). Encouraging the economic environment diminishes the barrier of financing for firms (Cepel et al., 2019). Access to finance is a key variable affecting the growth of firms, thus the next hypothesis is framed to test difference in perception regarding access to finance environment by service and non-service firms.

The government can create favorable conditions for business (Van Den Bosch \& De Man, 1994). Officials have a significant role in nurturing a healthy business environment for the SMEs' successful development setting up rules and regulations to increase the certainty of business operations as the inappropriate guidelines hamper entrepreneurs in business start-ups and nurturing new business (Aristovnik \& Obadić, 2019). Government policies must support and encourage entrepreneurship and small business development through rewards to innovate and to support and promote entrepreneurship to yield innovation, there must be increments in returns and reduction of risks (Michael \& Pearce, 2009) as entrepreneurship promotes economic activities (Bahmani, Galindo, \& Méndez, 2012). The competitive environment encompasses barriers to entry, buyer power, supplier power, the threat of substitution, and competitive rivalry (the concept of Porter's five forces). The narrower idea of the business environment includes direct competitors, customers, suppliers, and employees (Cepel et al., 2018). Government policies also do have an impact on competitiveness (Van Den Bosch \& De Man, 1994) and it was also found competition may improve performance (Nickell, 1996). That's why now firms are recognizing the significance of competitive environmental scanning and want to work more in that area (Trieloff \& Buys, 2013) as it is one of the crucial parts of the business environment. Stimulating competition is generally accepted as the best available means for stimulating consumer well-being but it is also important that bureaucrats must comprehend when competition itself becomes the cause of the problem (Stucke, 2013). To provide fair competition to promote the growth of firms, it is logical to test and determine the competition environment evaluation by the service and non-service firms, thus the following hypothesizes has been set-up to test:

H1: There are statistically significant differences in the perception of the macroeconomic environment between service and non-service firms.

$\mathrm{H} 2$ : There are statistically significant differences in the perception of the consumer consumption pattern between service and non-service firms.

H3: There are statistically significant differences in the perception of access to finance between service and non-service firms.

H4: There are statistically significant differences in the perception of business support between service and non-service firms. 
H5: There are statistically significant differences in the perception of competition between service and non-service firms.

\section{Aim, data and Methods}

\subsection{Aim}

This paper aimed to identify the differences in the entrepreneur's perception about the quality of the business environment in two broad segments of firms, classified into two groups, firms involved in the services business and the firms involved in non-services business in the Czech Republic as well as a comparison of the firms' perception in two similar economics the Czech and the Slovakia Republics. To achieve the identified aim, survey-based research was conducted with enterprises operating in service and nonservice segments in the Czech and the Slovakia Republics was approached to collected data to achieve the set objectives of the study.

\subsection{Data}

The random choice approach using the mathematical function "Randbetween" was used to pick companies from the database "Albertína" consisting of companies in the Czech Republic. The study had selected the Slovak companies randomly from the "Cribis" database containing the list of companies, organizations, and entrepreneurs. The firms were contacted through electronic mails and collected the structured questionnaire which was specifically filled by the firm's owners and the entrepreneurs managing them. All the data were collected in the year 2018 .

In the Czech Republic, the response rate was about 4 percent (out of more than 7,800 companies). In the Slovak Republic, the number of firms contacted was over 9,400 and the response rate was approximately 3.5\%.The data collected in the Czech Republic covered 312 enterprises, include the following details of the respondents, in business area: 109 enterprises belong to services and 203 enterprises belong to non-service areas inclusive of manufacturing, agriculture, etc. On the basis of the age of the enterprises, 56 enterprises fall in the age bracket of 1-5 years, 48 falls in the bracket of 5-10 years and 208 enterprises aged more than 10 years. On the basis of the size of the business, 258 were micro-enterprises had a maximum of 10 employees, 43 were small enterprises had employees maximum of 50 employees and 11 medium scale enterprises had employees maximum of 250. Considering the educational levels of the entrepreneurs, 50 entrepreneurs had a high school without a diploma, 153 had a high school with a diploma and 127 had college-level education. There were 236 men entrepreneurs and 76 female entrepreneurs.

The data collected in Slovak republic covered 329 firms and consist of the following profile, on the basis of the business area, 122 were services enterprises and 207 were non-services enterprises inclusive of manufacturing, agriculture, etc. On the basis of age of the enterprises, 104 were 1-5 years old, 78 were between 5-10 years old and 147 were more than 10 years old. On the basis of the size of the firms' majority 234 belongs to micro-enterprises had a maximum of 10 employees, 71 were small enterprises had a maximum of50 employees and 24 were medium-sized had a maximum of 250 employees. On the basis of the educational level, 10 entrepreneurs had a high school without a diploma, 95 had a high school with a diploma and the majority 224 had a college 
education. Out of a total of 251 entrepreneurs were male and rest 78 were female entrepreneurs.

All together 641 firms data were used in the study collected from both the countries, 51.3\% belongs Slovak firms and 48.7\% Czech Republic. Out of total 641, 25\% i.e. 160 were young firms fall under the age of 1-5, 19.7\% i.e. 126 firms aged between 510 years and majority $55.4 \%$ were older than 10 years. Majority 492 i.e. $76.8 \%$ were micro enterprises, $11417.8 \%$ were small firms and the rest 35 i.e. 5.5\% were medium enterprises. On the basis of service and non-service classification, out of a total of 641, 231 i.e.36.04\% enterprises were belonging to service sector and 410 i.e. $63.96 \%$ enterprises related with non-service sector.

Table 1. Sample profile

\begin{tabular}{|c|c|c|c|c|c|c|c|}
\hline & \multicolumn{4}{|c|}{ Sector } & \multirow{2}{*}{\multicolumn{2}{|c|}{ Total }} \\
\hline & & \multicolumn{2}{|c|}{ Service } & \multicolumn{2}{|c|}{ Non-service } & & \\
\hline & & $\mathrm{N}$ & $\%$ & $\mathrm{~N}$ & $\%$ & $\mathrm{~N}$ & $\%$ \\
\hline \multirow[t]{3}{*}{ Country } & Slovakia & 122 & $52.8 \%$ & 207 & $50.5 \%$ & 329 & $51.3 \%$ \\
\hline & Czech Republic & 109 & $47.2 \%$ & 203 & $49.5 \%$ & 312 & $48.7 \%$ \\
\hline & $\overline{\text { Total }}$ & 231 & $100 \%$ & 410 & $100 \%$ & 641 & $100 \%$ \\
\hline \multirow[t]{4}{*}{ Firm age } & $1-5$ years & 59 & $25.5 \%$ & 101 & $24.6 \%$ & 160 & $25.0 \%$ \\
\hline & $5-10$ years & 48 & $20.8 \%$ & 78 & $19.0 \%$ & 126 & $19.7 \%$ \\
\hline & More than 10 years & 124 & $53.7 \%$ & 231 & $56.3 \%$ & 355 & $55.4 \%$ \\
\hline & Total & 231 & $100 \%$ & 410 & $100 \%$ & 641 & $100 \%$ \\
\hline \multirow[t]{4}{*}{ Firm size } & Micro (up to 10 employees) & 191 & $82.7 \%$ & 301 & $73.4 \%$ & 492 & $76.8 \%$ \\
\hline & Small (10 - 50 employees) & 33 & $14.3 \%$ & 81 & $19.8 \%$ & 114 & $17.8 \%$ \\
\hline & $\begin{array}{l}\text { Medium (up to } 250 \\
\text { employees) }\end{array}$ & 7 & $3.0 \%$ & 28 & $6.8 \%$ & 35 & $5.5 \%$ \\
\hline & Total & 231 & $100 \%$ & 410 & $100 \%$ & 641 & $100 \%$ \\
\hline
\end{tabular}

Source: Authors calculations

According to the approach stated by Conorto et al. (2014), adapted from (Cepel et al., 2018) five types of business environment identified in the research, using the statements to investigate the perception of firms: macro environment covered four items about starting, doing and supporting business, consumer's consumption also covered four items and are related with consumer's consumption influences on business environment, access to finance includes the question related how easy or complex is financing, business support covered about state support and the last is competitive environment intended to know the perception about competitiveness of the market (See Appendix). These indicators were used even by other scholars (Belas et al., 2019; Çera, Belás, \& Strnad, 2019).

\subsection{Method}

To explore for differences between two categories of sectors in selected factors of business environment, independent sample t-test was performed. However, this test has some assumptions. The violation of any of them lead to the fact that independent sample t-test cannot be performed because otherwise it misleads. In cases when these assumptions were not satisfied, nonparametric methods can be applied (Gravetter \& Wallnau, 2017). The nonparametric test equivalent to independent sample t-test is called Mann-Whitney test. It calculates the mean ranks per each group and then it tests whether 
any statistical difference between these two groups is or not, by informing even for which group has higher or smaller scores in the respective variables.

\section{Results}

As mentioned earlier, 20 indicators were formulated as statements and used to capture entrepreneurs' perceptions on several dimensions of the business environment such as access to finance, consumers, macroeconomic environment, business support, and competition (see Appendix). In a way to reduce this number of variables, the principal component analysis was performed (Fabrigar \& Wegener, 2011). The factor analysis helped summaries entrepreneurs' perceptions of 20 indicators into a smaller number of underlying factors. Factors with eigenvalues above one were kept. Nonetheless, one indicator (sup2) was removed from the analysis, due to very low values of communalities and loading values. Five factors emerged from the principal component analysis, explaining $56.32 \%$ of the variance. The Kaiser-Meyer-Olkin value was greater than the border of 0.70 and Barlett's test was statistically significant (Hair, Black, Babin, \& Anderson, 2010), indicating evidence in support of the appropriateness of factor analysis. The final rotated matrix is in Table 2.All factor loadings were well above the 0.40 threshold of Stevens (2015), providing evidence of the convergent validity of constructs.

Table 2. Rotated component matrix

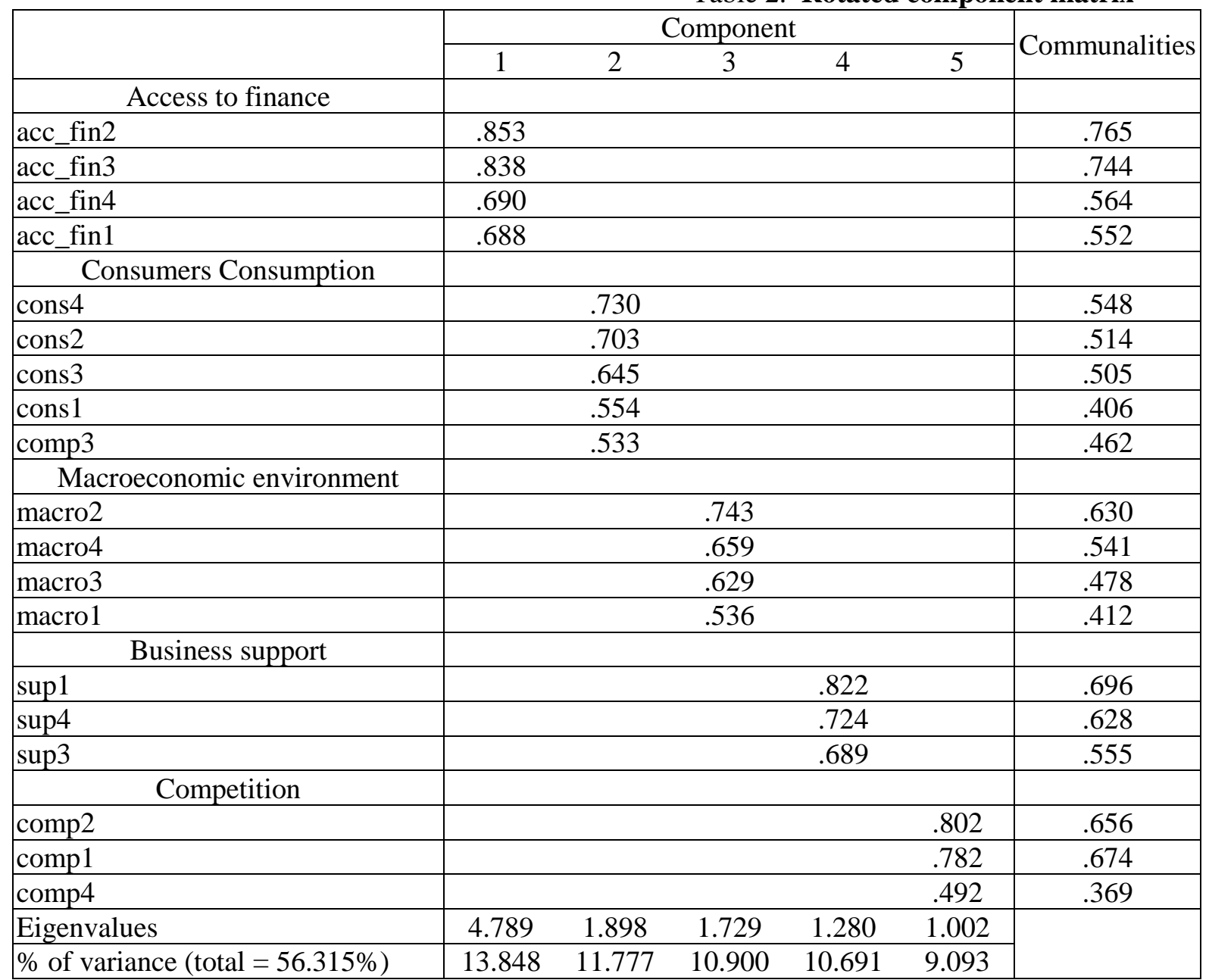


Source: Authors' calculation. Note: Extraction method: Principal Component Analysis. Rotation method: Varimax with Kaiser normalization. Rotation converged in 6 iterations. Kaiser-Meyer-Olkin Measure of sampling adequacy $=.838$. Sig. Bartlett's test $<.001$. Correlation matrix's determinant $=.007$; Coefficient loading displayed $>|0.40|$.

The first factor was loaded by four indicators related to access to finance, explaining $13.85 \%$ of the variance in the sample. The second factor had an eigenvalue of 1.898 and explained $11.78 \%$ of the variance. It was a result of four items dealing with consumer consumptions and one item that initially was expected to load under the competition component. A detail investigation can justify this result. The reason is behind the way how that indicator was formulated, 'My customers accept the prices of my products and services', showing the connection with consumer consumption's factor. The third factor was named 'macroeconomic environment' because it was loaded by four items dealing with such an environment. It explained $10.9 \%$ of the variance in the sample. The fourth factor was labelled 'business support' because three items pointed at governmental business support, explaining $10.69 \%$ of the variance. The final factor was named "competition" as its indicators were covering the competition environment. Its eigenvalue was 1.002 and it explained almost ten percent of the variance in the sample. These components were accounted for to follow-up the investigation in the way to test the planned hypotheses.

In a way to investigate for differences between sectors (service vs non-service sectors) in the emerged factors from factor analysis, an independent t-test can be performed. However, this statistical technique requires that the variables should be normally distributed (Gravetter \& Wallnau, 2017). In cases when this assumption is not fulfilled, a non-parametric statistical technique should run instead, such as the MannWhitney test. To explore whether or not this assumption is fulfilled, Shapiro-Wilk and Kolmogorov-Smirnov tests were executed. Table 3 shows the results of the latter tests. Only the factor covering the macroeconomic environment was not normally distributed, indicating the use of an independent t-test. For the other factors, both tests revealed that the assumption of normal distribution was violated signifying the use of the MannWhitney test instead of an independent t-test.

Table 3. Tests of normality

\begin{tabular}{|l|cc|cc|c|}
\hline & \multicolumn{2}{|c|}{ Kolmogorov-Smirnov } & \multicolumn{2}{|c|}{ Shapiro-Wilk } & \multirow{2}{*}{ Which test? } \\
\hline Statistic & Sig. & Statistic & Sig. & \\
\hline Access to finance & .058 & .000 & .986 & .000 & Mann-Whitney \\
\hline Consumers Consumption & .067 & .000 & .974 & .000 & Mann-Whitney \\
\hline Macroeconomic environment & .035 & .065 & .997 & .228 & Independent t-test \\
\hline Business support & .065 & .000 & .976 & .000 & Mann-Whitney \\
\hline Competition & .110 & .000 & .935 & .000 & Mann-Whitney \\
\hline
\end{tabular}

Source: Authors' calculation. Note: a. Lilliefors Significance Correction

Tables 4 and 5 inform for the independent sample test for the factor that resulted normally distributed, which was the 'macroeconomic environment'. In Table 4 are shown some group statistics for both categories of sectors in two countries: Slovakia and the Czech Republic. As it can be seen, in the case of Slovakia, the mean of 'macroeconomic environment' changed sign from negative for non-service to positive for service. Therefore, it was expected that between these two categories there is a statistical difference in perceiving the macroeconomic environment. Indeed, the independent t-test showed that difference is statistically significant, $t(327)=-1.845, p<0.10$. Thus, Slovak firms in the service sector scored higher in macroeconomic environment factors, as compared to their non-service counterparts. 
Table 4. Group statistics 'macroeconomic environment'

\begin{tabular}{|ll|cccc|}
\hline Country & Sector & $\mathrm{N}$ & Mean & Std. Deviation & Std. Error Mean \\
\hline Slovakia & Non-service & 207 & -.165 & 1.013 & .070 \\
\cline { 2 - 6 } & Service & 122 & .045 & .973 & .088 \\
\hline Czech & Non-service & 203 & .111 & .966 & .068 \\
Republic & Service & 109 & .058 & 1.040 & .100 \\
\hline
\end{tabular}

Source: Authors' calculations

The same test was applied even in the case of Czech entrepreneurs, which showed no significant difference between two business sectors, $t(310)=0.445, p>0.10$. The mean of macroeconomic environment for both service and non-service businesses were positive, 0.058 and 0.111 respectively.

Table 5. Independent samples test for 'macroeconomic environment'

\begin{tabular}{|c|c|c|c|c|c|c|c|c|}
\hline \multirow[b]{2}{*}{ Country } & \multirow[b]{2}{*}{$\begin{array}{l}\text { Equal } \\
\text { variances? }\end{array}$} & \multicolumn{2}{|c|}{ Levene'stest $^{\mathrm{a}}$} & \multicolumn{5}{|c|}{$t$-test ${ }^{b}$} \\
\hline & & $\mathrm{F}$ & Sig. & $t$ & df & $p$ & $\begin{array}{c}\text { Mean } \\
\text { difference }\end{array}$ & $\begin{array}{l}\text { Std. Error } \\
\text { difference }\end{array}$ \\
\hline \multirow[t]{2}{*}{ Slovakia } & Assumed & 0.072 & .789 & $\begin{array}{c}- \\
1.845\end{array}$ & 327 & .066 & -0.210 & 0.114 \\
\hline & Not assumed & & & $\begin{array}{c}- \\
1.865\end{array}$ & 262.313 & .063 & -0.210 & 0.113 \\
\hline Czech & Assumed & 1.674 & .197 & .445 & 310 & .657 & 0.052 & 0.118 \\
\hline Republic & Not assumed & & & .435 & 207.527 & .664 & 0.052 & 0.120 \\
\hline
\end{tabular}

Source: Authors' calculation. Note: a. for Equality of Variances; b. for Equality of Means

In respect to the normality test's results, to investigate for differences in access to finance, consumers, business support and competition factors between firms operating in the service sector and those in the other sectors, the Mann-Whitney test was executed. Its results are presented in Table 6 for both the Czech Republic and Slovakia. In the case of Slovak firms, it appeared that, excluding the factor pointing at business support $(U=$ $12089, z=-0.646, p>0.10$ ), all the other factors statistically differ between service firms and their non-service counterparts. Hence, Slovak firms operating in the non-service sector scored higher in access to finance, when compared to those in the service sector, $U=10680, z=-2.336, p<0.05$. On the other hand, when compared to firms operating in service sector, those in no-service scored significantly lower in 'consumers' $(U=11171$, $z=-1.747, p<0.10$ ) and 'competition' factors, $U=11110, z=-1.820, p<0.10$. Therefore, there was a linkage between the business sector and selected business environment factors, such as macroeconomic environment, access to finance, consumers and competition.

Table 6. Results of Mann-Whitney test for differences between sectors per each country

\begin{tabular}{|ll|rc|ccc|}
\hline \multirow{2}{*}{ Country } & \multicolumn{2}{|c|}{ Mean rank } & \multicolumn{3}{c|}{ Mann-Whitney test } \\
\hline \multirow{5}{*}{ Slovakia } & Factor & Service & Non-service & $U$ & $z$ & $p$ \\
\cline { 2 - 7 } & Consumers to finance & 149.04 & 174.41 & 10680 & -2.336 & .019 \\
\cline { 2 - 7 } & Business support & 176.93 & 157.97 & 11171 & -1.747 & .081 \\
\cline { 2 - 7 } & Competition & 169.41 & 162.40 & 12089 & -0.646 & .519 \\
\hline \multirow{2}{*}{$\begin{array}{l}\text { Czech } \\
\text { Republic }\end{array}$} & Access to finance & 153.43 & 157.67 & 11110 & -1.820 & .069 \\
\cline { 2 - 7 } & Consumers consumption & 162.98 & 158.23 & 10712 & -0.463 & .644 \\
\cline { 2 - 7 } & Business support & 149.83 & 160.08 & 10336 & -0.958 & .338 \\
\hline
\end{tabular}




\begin{tabular}{|c|cc|ccc|}
\hline Competition & 159.14 & 155.08 & 10776 & -0.378 & .705 \\
\hline
\end{tabular}

Source: Authors' calculations

Contrary to the Slovak case, the Czech entrepreneurs' perception did not statistically differ in any factor between those firms operating in service and those in nonservice sectors. The only similarities between Slovak and Czech entrepreneurs in this regard are that between firms in the service sector and the other did not differ in perception of business support, $U=10336, z=-0.958, p>0.10$. For more details in this regard, see Table 6. Thus, in the Czech case, the current paper failed to find any linkage between the business sector and selected business environment factors, such as macroeconomic environment, access to finance, consumers, business support and competition.

\section{Discussion}

The outcomes of the research indicate that there are no significant differences regarding perceived quality of business environment among Czech firms, but in Slovak firms' significant difference were found in all the selected variable of business environment except business support. Moreover, the outcome differ between the two countries (Czech Republic and Slovakia). However, these results should be discussed a bit more carefully and are subject to further details study at broad level. The study used Independent t-test for macro-economic environment and the results supported the hypothesis in the case of Slovak republic and non-parametric test Mann-Whitney test for other variables where all hypotheses accepted, except $\mathrm{H} 4$ in case of Slovakia republic, and in the case of Czech Republic all the hypothesis are rejected. Therefore study failed to find any linkage between Czech business sector and business environment. There is a strong need to study carefully the real problems of different groups of enterprises. The impact of certain perceived critical success factors for example techno-regulatory environment may not be the similar for firms in the retail sector and firms in the manufacturing or agricultural sectors (Pansiri \& Temtime, 2010).

Excluding the hypothesis $\mathrm{H} 4$, the evidence supported all hypotheses in the case of Slovak entrepreneurs. Contrary to the Slovak case, firms operating in the Czech Republic reflected no statistically significant in any of the proposed hypotheses, rejecting all of them. In the case of Slovak republic, only business support detected no statistically significant difference between the perception of service and non-service firms, therefore hypothesis four is rejected. Hypotheses H1, H2, H3and H5, are confirmed as the study found a statistically significant difference between the perception of service and nonservice firms in Slovakia. In the case of the Czech Republic, all the proposed hypotheses are rejected $\mathrm{H} 1, \mathrm{H} 2, \mathrm{H} 3, \mathrm{H} 4$ and $\mathrm{H} 5$, therefore all the proposed hypothesis are statistically rejected in the Czech Republic. It also reflect that there is no similarity in the perception of the entrepreneurs between Czech Republic and Slovakia Republic, the results are in line of the studies covered differences between countries(Çera, Belas, Martin, \& Zoltan., 2019; Essia, 2012)

Table 6. Regarding access to finance non-service firms scored significantly higher (174.41) in Slovakia than service firms (149.04) and in other cases consumer's consumption (176.93), business support (169.41), and competition (177.43) service firms scored higher than non-service firms in Slovakia, it indicates for non-service firms access to finance is more critical aspect than others and for service firms' consumer consumption, business support and competition is highly vital than other aspects. Comparatively, access to finance (158.23) and business support (160.08) scored higher 
in non-service firms and regarding consumer's consumption (162.98) and competition (159.14) scored higher by service firms in the Czech Republic. Therefore, for non-service firms, access to finance and business support is more critical and for service firms' consumer's consumption and competition are very vigorous.

The results of the study are in line with studies focused on the sectors, and highlight the importance and role of sectors in the perception of the quality of the business environment (Saghir \& Aston, 2018).Indeed, the results showed the different perception in the case of the Czech Republic and the Slovak Republic, interestingly no differences found in Czech and the only difference found in Slovakia is related to business support, the current study is conducted on the basis of sector, where service and non-service firms are separately classified to test their perception differences and it in line with some similar study focused on quality of business environment on the basis of sector.

\title{
6. Conclusion
}

The study conclude the congenial quality of the business environment is the basic need for the development of entrepreneurship and SMEs, no doubt they are the backbone of the economic advancement as well as provide indirect benefits to society and community through employment generation, production, etc. To provide the strength and support a favorable business environment has to be created. It is logical to evaluate the perception of the quality of the business environment for its further improvement and betterment. That's what the current study did, the study classified all firms into service and nonservice and tried to find the statistical differences in the perception of entrepreneurs and business owners of micro, small and medium enterprises in two similar economy, and the study found there is statistically significant difference in term of business support and no difference in perception regarding macroeconomic environment, access to finance, consumer consumption and competition in Slovakia republic. The study failed to find any statistical difference in the perception of the quality of the business environment between the service and non-service firms in the Czech Republic.

Apart from the findings of the paper, the study is not free from limitations although the statistical method revealed insignificant differences in perception of entrepreneurs in the context of the Czech Republic between service and non-service firms, and in Slovakia regarding all found statistically significant differences in the perception of service and non-service firms expect in term of business support. This limitation can be overcome with further research by replicating it to the other countries. From the methodological point of view, more rigor methods can be used to test the proposed hypotheses in a similar kind of study.

\section{Acknowledgment}

This paper was supported by the Internal Grant Agency of Faculty of Management and Economics, Tomas Bata University, no. IGA/FaME/2019/002: The role of institutional environment in fostering entrepreneurship.

\author{
Appendix \\ Variable measurement (Source: Conorto et al. (2014), adapted from (Cepel et al., 2018) \\ Code Description \\ Macroeconomic environment
}




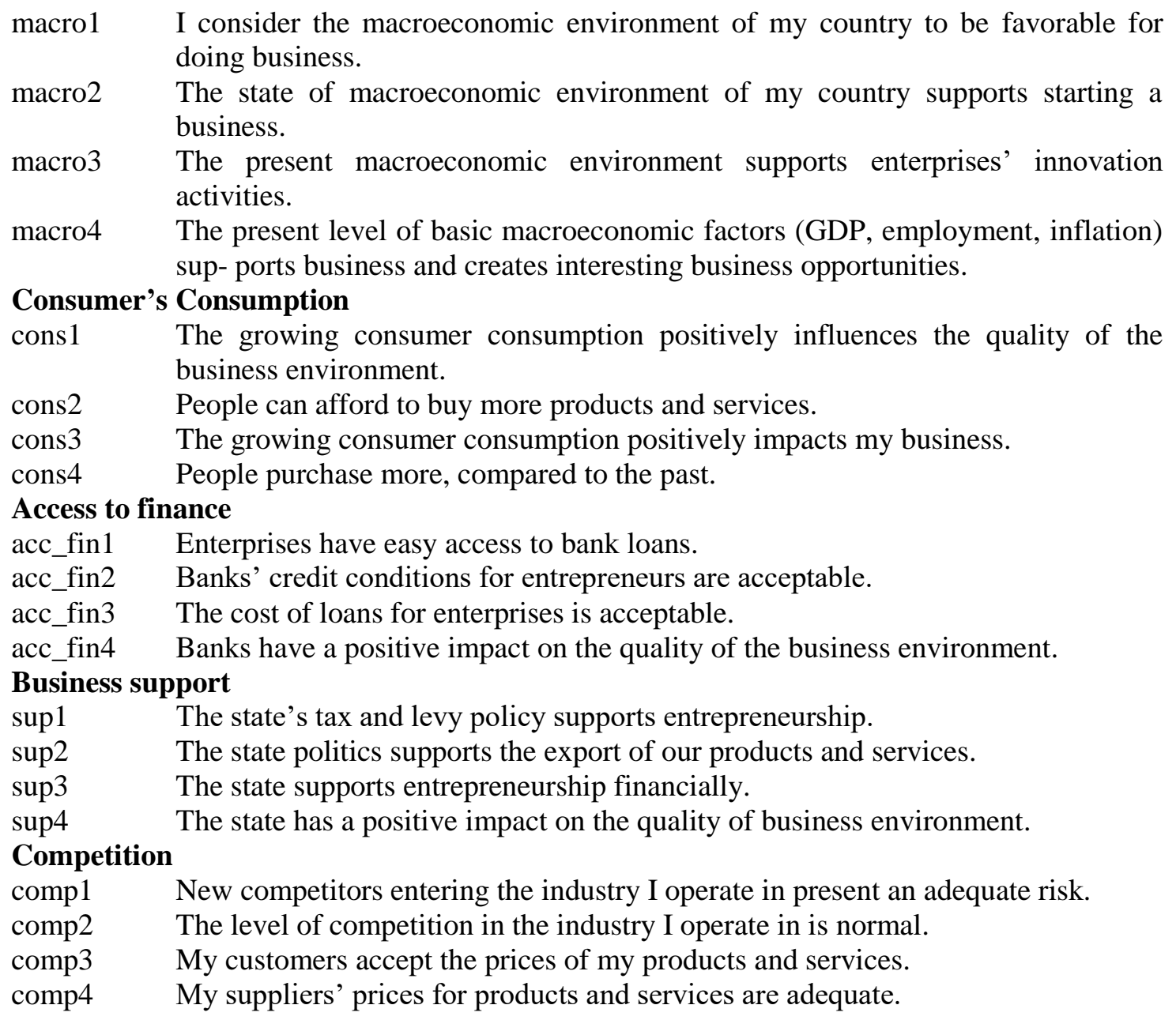

\section{References}

1. Ahmedova, S. (2015). Factors for Increasing the Competitiveness of Small and Medium- Sized Enterprises (SMEs) in Bulgaria. Procedia - Social and Behavioral Sciences, 195, 1104-1112. https://doi.org/10.1016/j.sbspro.2015.06.155

2. Androniceanu, A. (2017). The three-dimensional approach of Total Quality Management, an essential strategic option for business excellence, Amfiteatru Economic, 19(44), 61-78.

3. Angelini, E., \& Foglia, M. (2018). The relationship between IPO and macroeconomics factors: An empirical analysis from UK market. Annals of Economics and Finance, 19(1), 319-336.

4. Aristovnik, A., \& Obadic, A. (2015). The impact and efficiency of public administration excellence on fostering SMEs in EU countries. Amfiteatru Economic, 17(39), 761-774. Retrieved from http://search.proquest.com/openview/60306e896249716a610b374b2c855283/1? pq-origsite $=$ gscholar \&cbl $=1926338$

5. Bahmani, S., Galindo, M. Á., \& Méndez, M. T. (2012). Non-profit organizations, entrepreneurship, social capital and economic growth. Small Business Economics, 38(3), 271-281. https://doi.org/10.1007/s11187-010-9274-7

6. Bekeris, R. (2012). The impact of macroeconomic indicators upon SME's profitability (Makroekonomikos veiksnių itaka smulkaus ir vidutinio verslo imoniu pelningumui). Vilniaus Universitetas, Tarptautinio Verslo Mokykla, Lietuva, 91(3), 1392-1258. 
7. Belas, J., Belas, L., Cepel, M., \& Rozsa, Z. (2019). The impact of the public sector on the quality of the business environment in the SME segment. Administratie $\mathrm{Si}$ Management Public, 2019(32), 18-31. https://doi.org/10.24818/amp/2019.32-02

8. Besley, T. (2015). Law, Regulation, and the Business Climate: The Nature and Influence of the World Bank Doing Business Project. The Journal of Economic Perspectives, 29, 99-120. https://doi.org/10.2307/43550123

9. Bruothová, M., \& Hurný, F. (2016). Selected characteriSticS of BuSineSS environment in viSegrad region. Central European Journal of Management, 2(1,2), 23-35. https://doi.org/10.5817/cejm2015-1-2-3

10. Buno, M., Nadanyiova, M., \& Hraskova, D. (2015). The Comparison of the Quality of Business Environment in the Countries of Visegrad Group. Procedia Economics and Finance, 26(15), 423-430. https://doi.org/10.1016/s22125671(15)00826-6

11. Carla Drysdale. (2018). World Economic Situation and Prospects 2018. United Nations New York.

12. Cepel, M., Belas, J., \& Strnad, Z. (2019). Selected economic factors of the quality of business environment. Journal of International Studies, 12(2), 228-240. https://doi.org/10.14254/2071-8330.2019/12-2/1410.14254/2071-8330.2019/12$2 / 14$

13. Cepel, M., Stasiukynas, A., Kotaskova, A., \& Dvorsky, J. (2018). Business environment quality index in the SME segment. Journal of Competitiveness, 10(2), 21-40. https://doi.org/10.7441/joc.2018.02.02

14. Çera, G., Belas, J., Martin, C., \& Zoltan., R. (2019). Linking firm characteristics to perceived important social factors for entrepreneurial activity. Economics and Sociology, 12(4).

15. Çera, G., Belás, J., \& Strnad, Z. (2019). Important factors which predict entrepreneur's perception in business risk. Problems and Perspectives in Management, 17(2), 415-429. https://doi.org/10.21511/ppm.17(2).2019.32

16. Chávez, É., Koch-Saldarriaga, K., \& Maria, Q. (2018). IMPROVING ACCESS TO FINANCE FOR SMES, Opportunities through Credit Reporting, Secured Lending and Insolvency Practices.

17. Chládková, H. (2015). Selected Approaches to the Business Environment Evaluation. Acta Universitatis Agriculturae et Silviculturae Mendelianae Brunensis, 63(2), 515-523. https://doi.org/10.11118/actaun201563020515

18. Çiftçi, S. (2014). The Influence of Macroeconomic Variables on Stock Performance. University $f \quad$ Twente, (December). https://doi.org/10.1007/BF02685067

19. Commander, S., \& Svejnar, J. (2011). Business environment, exports, ownership, and firm performance. The Review OfEconomics and Statistics, 93(1), 309-337.

20. Dababneh, R., Tukan, F., European Commission, Oteh, B. A., Commission, S. E., Turyahikayo, E., ... Ramalho, R. (2015). MAKING CAPITAL MARKETS WORK FOR SMEs in AFRICA. Brooking Global Economy And Development (Vol. 13). https://doi.org/10.2873/782201

21. Dewi, V. I., Soei, C. T. L., \& Surjoko, F. O. (2019). The impact of macroeconomic factors on firms' profitability (evidence from fast moving consumer good firms listed on Indonesian stock exchange). Academy of Accounting and Financial Studies Journal, 23(1), 1-6.

22. Dobes, K., Kot, S., Kramolis, J., \& Sopkova, G. (2017). The Perception of Governmental Support in The Context of Competitiveness of SMEs in the Czech Republic. Journal of Competitiveness, 9(3), 34-50. 
https://doi.org/10.7441/joc.2017.03.03

23. Dvorský, J., Petráková, Z., Zapletalíková, E., \& Rózsa, Z. (2019). Entrepreneurial propensity index of university students. The case study from the Czech Republic, Slovakia and Poland. Oeconomia Copernicana, 10(1), 173-192. https://doi.org/10.24136/oc.2019.009.

24. Egbunike, C. F., \& Okerekeoti, C. U. (2018). Macroeconomic factors, firm characteristics and financial performance. Asian Journal of Accounting Research, 3(2), 142-168. https://doi.org/10.1108/ajar-09-2018-0029

25. Essia, U. (2012). Business Environment and Competitiveness in Nigeria Considerations for Nigeria' s Vision 2020. International Research Journal of Finance and Economics, (97).

26. Fabrigar, L. R., \& Wegener, D. T. (2011). Exploratory Factor Analysis. New York, NY: Oxford University Press.

27. Fowowe, B. (2017). Access to finance and firm performance: Evidence from African countries. Review of Development Finance, 7(1), 6-17. https://doi.org/10.1016/j.rdf.2017.01.006

28. Goldstein, S. M., Johnston, R., Duffy, J. A., \& Rao, J. (2002). The service concept: The missing link in service design research? Journal of Operations Management, 20(2), 121-134. https://doi.org/10.1016/S0272-6963(01)00090-0

29. Gosevska, Ms. L., Popovski, D. S. V., \& Markoski, Ms. G. (2013). The role and influence of entrepreneurship on the growth and expanding of small and medium enterprises in the Republic of Macedonia. ILIRIA International Review, 3(1), 89. https://doi.org/10.21113/iir.v3i1.100

30. Gravetter, F. J., \& Wallnau, L. B. (2017). Statistics for the behavioral sciences (10th ed.). CENGAGE Learning.

31. Hair, J. F., Black, W. C., Babin, B. J., \& Anderson, R. E. (2010). Multivariate Data Analysis (7th Editio). Harlow: Pearson Education Limited.

32. Hudáková, M., \& Dvorský, J. (2018). Assessing the risks and their sources in dependence on the rate of implementing the risk management process in the SMEs. Equilibrium. Quarterly Journal of Economics and Economic Policy, 13(3), 543-567. https://doi.org/10.24136/eq.2018.027.

33. Ipinnaiye, O., Dineen, D., \& Lenihan, H. (2017). Drivers of SME performance: a holistic and multivariate approach. Small Business Economics, 48(4), 883-911. https://doi.org/10.1007/s11187-016-9819-5

34. Kaufmann, H. R., \& Panni, M. F. A. K. (2014). Handbook of research on consumerism in business and marketing: Concepts and practices. Handbook of Research on Consumerism in Business and Marketing: Concepts and Practices. https://doi.org/10.4018/978-1-4666-5880-6

35. Kljucnikov, A. (2016). Uncover SMEs finance through the impact of the specific factors. Evidence from Slovakia. Transformations in Business and Economics, 15(2B), 741-754.

36. Kljucnikov, A., \& Belas, J. (2016). Approaches of Czech entrepreneurs to debt financing and management of credit risk. Equilibrium Quarterly Journal of $\begin{array}{llll}\text { Economics and Economic Policy, } & 343 .\end{array}$ https://doi.org/10.12775/EQUIL.2016.016

37. Kljucnikov, A., Belas, J., Kozubikova, L., \& Pasekova, P. (2016). The Entreprenurial Perception of SME Business Environment Quality in the Czech Republic. Journal of Competitiveness, 8(1), 66-78. https://doi.org/10.7441/joc.2016.01.05

38. Kotaskova, A., \& Rozsa, Z. (2019). The Impact of Selected Factors on the Quality 
of Business Environment Assessment in the Czech Republic and the Slovak Republic. International Journal of Entrepreneurial Knowledge, 6(2), 71-80. https://doi.org/10.2478/ijek-2018-0015

39. Kozubíková, L., Homolka, L., \& Kristalas, D. (2017). The Effect of Business Environment and Entrepreneurs' Gender on Perception of Financial Risk in The Smes Sector. Journal of Competitiveness, 9(1), 36-50. https://doi.org/10.7441/joc.2017.01.03

40. KPMG. (2015). The new wave Indian MSME.

41. Lewandowska, A., \& Stopa, M. (2019). Do SME's innovation strategies influence their effectiveness of innovation? Some evidence from the case of Podkarpackie as peripheral region in Poland. Equilibrium. Quarterly Journal of Economics and Economic Policy, 14(3), 521-536. https://doi.org/10.24136/eq.2019.025.

42. Michael, S. C., \& Pearce, J. A. (2009). The need for innovation as a rationale for government involvement in entrepreneurship. Entrepreneurship and Regional Development, 21(3), 285-302. https://doi.org/10.1080/08985620802279999

43. Nickell, S. J. (1996). Competition and Corporate Performance. Journal of Political Economy, 104(4), 724-746. Retrieved from http://www.jstor.org/stable/213888

44. Noorali, M., \& Gilaninia, S. (2017). The Role of Small and Medium - Sized Enterprises in Development. Nigerian Chapter of Arabian Journal of Business and Management Review, 4(4), 36-40. https://doi.org/10.12816/0040342

45. OECD. (2005). Growth in Services. OECD Publications France. https://doi.org/10.1787/9789264064577-en

46. Pansiri, J., \& Temtime, Z. T. (2010). Linking firm and managers' characteristics to perceived critical success factors for innovative entrepreneurial support. Journal of Small Business and Enterprise Development, 17(1), 45-59. https://doi.org/10.1108/14626001011019125

47. Rahman, A., Belas, J., Kliestik, T., \& Tyll, L. (2017). Collateral requirements for SME loans: empirical evidence from the Visegrad countries. Journal of Business Economics and Management, 18(4), 650-675. https://doi.org/10.3846/16111699.2017.1357050

48. Ribeiro-Soriano, D. (2017). Small business and entrepreneurship: their role in economic and social development. Entrepreneurship and Regional Development, 29(1-2), 1-3. https://doi.org/10.1080/08985626.2016.1255438

49. Saghir, M., \& Aston, J. (2018). The Impact of Various Economic Factors in accessing Finance within the Business Sector : Cases from UK Financial Services Companies. Munich Personal RePEc Archive The, (84052).

50. Stucke, M. E. (2013). Is competition always good? Journal of Antitrust Enforcement, 1(2), 162-197. https://doi.org/10.1093/jaenfo/jns008

51. Trieloff, W., \& Buys, P. W. (2013). An analysis of the competitive business environment of a family run Brazilian auditing firm. International Journal of Auditing Technology, 1(1), 52. https://doi.org/10.1504/ijaudit.2013.052261

52. Trofimovs, I. (2017). JOURNAL OF SECURITY AND SUSTAINABILITY ISSUES ISSN 2029-7017 print / ISSN 2029-7025 online 2017 September Volume 7 Number 1, 6(1), 85-102.

53. Van Den Bosch, F. A. J., \& De Man, A.-P. (1994). Government's Impact on the Business Environment and Strategic Management. Journal of General Management, 19(3), 50-59. https://doi.org/10.1177/030630709401900304

54. Vydrová, J., Bejtkovský, J. (2018). The importance of the individual pillars of social maturity of workers in healthcare organizations in the hierarchy of pillars 
of competence in management. Administratie si Management Public, (31), pp. 2135, DOI: $10.24818 / \mathrm{amp} / 2018.31-02$

55. WB. (2019). Doing Business 2019: Training for Reform. World Bank, 304. https://doi.org/10.1596/978-1-4648-1326-9

56. Yap, C. W. S., \& Yazdanifard, R. (2014). How Consumer Decision Making Process Differ From Youngster to Older Consumer Generation. Journal of Research in Marketing, 2(2), 151. https://doi.org/10.17722/jorm.v2i2.54

57. Yoshino, N. (2016). Major Challenges Facing Small and Medium-Sized Enterprises in Asia and Solutions for Mitigating Them. SSRN Electronic Journal, (564). https://doi.org/10.2139/ssrn.2766242

58. Zajkowski, R., \& Domańska, A. (2019). Differences in perception of regional proentrepreneurial policy: does obtaining support change a prospect?. Oeconomia Copernicana, 10(2), 359-384. https://doi.org/10.24136/oc.2019.018.

\section{Brief description of Authors:}

\section{Khurram Ajaz Khan, PhD student}

Department of Business Administration, Faculty of Management and Economics, Tomas Bata University, Mostní 5139, Zlin 760 01, Czech Republic, E-mail: khan@utb.cz, ORCID: https://orcid.org/0000-0001-5728-8955. He is a PhD candidate in Finance at the mentioned University. His area of interest is financial literacy, financial capability, business environment, financial awareness and financial markets. He is also a member of a research project aiming fostering entrepreneurship.

\section{Gentjan Çera, PhD student}

Department of Business Administration, Faculty of Management and Economics, Tomas Bata University, Mostní 5139, Zlin 760 01, Czech Republic, cera@utb.cz, ORCID: https://orcid.org/0000-0002-9324-181X. He is a PhD student in Economic Policy and Administration at the above institution. He is also an assistant professor at Faculty of Economics and Agribusiness, Agricultural University of Tirana, Albania. His current research interest includes business environment, entrepreneurship and financial behavior. Currently, he is managing one scientific project in the field of entrepreneurship.

\section{Doc. Ing. Vaclav Netek, CSc.}

Department of Marketing, Institute of Entrepreneurship and Marketing, University of Entrepreneurship and Law, Prague, Czech Republic. www.vspp.cz, email: vaclav.netek@vspp.cz. Associate professor Netek focuses his research activities in the area of industrial marketing, and economics and management of small and mediumsized enterprises in the field of services. 